\title{
Revenue sharing or profit sharing? An internet production perspective
}

\author{
Gong, D. ${ }^{a}$, Liu, S. ${ }^{\text {a }}$, Tang, M. ${ }^{a}$, Ren, L. ${ }^{\text {b. }}$, Liu, J. ${ }^{c}$, Liu, X. ${ }^{d}$ \\ ${ }^{a}$ School of Economics and Management, Beijing Jiaotong University, Beijing, P.R. China \\ ${ }^{b}$ Research Center for Contemporary Management, Key Research Institute of Humanities and Social Sciences at Universities, \\ School of Economics and Management, Tsinghua University, Beijing, P.R. China \\ 'Institute of Economics, School of Social Science, Tsinghua University, Beijing, P.R. China \\ ${ }^{d}$ School of Business and Law, Foshan University, Guangdong, P.R. China
}

\begin{abstract}
A B S T R A C T
The booming of Internet economics brings new opportunities for small- and medium-sized product and service providers in e-platforms. Usually, the Internet platform (thereafter "platform") and Internet providers (thereafter "providers") operate under a consignment revenue sharing production model. Another production model is profit sharing, under which the platform undertakes part of the providers' operational costs. Intuitively, common sense conjectures that the platform prefers the revenue sharing model while the providers may prefer the profit sharing scheme. However, this is not the case. In this paper, we compare these two forms of emerging production models with a theoretical framework and investigate both market participants' performance under different schemes. Starting from the single provider case, we find that the provider has less incentive to operate under the revenue sharing contract when compared with the profit sharing contract. Counter intuitively, we identify the threshold of the cutting ratio above which it is more beneficial for the platform to choose the profit sharing mode. Our results are proved to be robust when the number of the providers increases. A numerical study is provided to illustrate this effect.
\end{abstract}

\section{ARTICLE INFO}

Keywords:

Horizontal competition;

Internet production;

Platform eco-system;

Profit sharing;

Revenue sharing

*Corresponding author:

renl.12@sem.tsinghua.edu.cn

(Ren, L.)

Article history:

Received 3 January 2018

Revised 19 February 2018

Accepted 21 February 2018

(C) 2018 PEI, University of Maribor. All rights reserved.

\section{References}

[1] Farrell, D., Greig, F. (2017). The online platform economy: Has growth peaked?, JP Morgan Chase Institute, New York, USA, doi: 10.2139/ssrn.2911194.

[2] Zervas, G., Proserpio, D., Byers, J.W. (2017). The rise of the sharing economy: Estimating the impact of Airbnb on the hotel industry, Journal of Marketing Research, Vol. 54, No. 5, 687-705, doi: 10.1509/imr.15.0204.

[3] Nunes, P.F., Bellin, J., Lee, I., Schunck, O. (2013). Converting the nonstop customer into a loyal customer, Strategy \& Leadership, Vol. 41, No. 5, 48-53, doi: 10.1108/sl-05-2013-0035.

[4] Dong, L., Ren, L., Zhang, D. (2017) Financing small and medium-sized sellers via E-commerce platform, Working paper, Washington University, St. Louis.

[5] Wang, Y., Jiang, L., Shen, Z.-J. (2004). Channel performance under consignment contract with revenue sharing, Management Science, Vol. 50, No. 1, 34-47, doi: 10.1287/mnsc.1030.0168.

[6] Christopher, M., Towill, D. (2001). An integrated model for the design of agile supply chains, International Journal of Physical Distribution \& Logistics Management, Vol. 31, No. 4, 235-246, doi: 10.1108/09600030110394914.

[7] Dana Jr., J.D., Spier, K.E. (2001). Revenue sharing and vertical control in the video rental industry, The Journal of Industrial Economics, Vol. 49, No. 3, 223-245, doi: 10.1111/1467-6451.00147.

[8] Gong, D., Tang, M., Liu, S., Li, Q. (2017). Reconsidering production coordination: A principal-agent theory-based analysis, Advances in Production Engineering \& Management, Vol.12, No.1, 51-61, doi: 10.14743/apem2017.1.239. 
[9] Giannoccaro, I., Pontrandolfo, P. (2004). Supply chain coordination by revenue sharing contracts, International Journal of Production Economics, Vol. 89, No. 2, 131-139, doi: 10.1016/s0925-5273(03)00047-1.

[10] Gerchak, Y., Wang, Y. (2004). Revenue-sharing vs. wholesale-price contracts in assembly systems with random demand, Production and Operations Management, Vol. 13, No. 1, 23-33, doi: 10.1111/j.1937-5956.2004.tb001 42.x.

[11] Cachon, G.P., Lariviere, M.A. (2005). Supply chain coordination with revenue-sharing contracts: Strengths and limitations, Management Science, Vol. 51, No. 1, 30-44, doi: 10.1287/mnsc.1040.0215.

[12] Cachon, G.P. (2003). Supply chain coordination with contracts, Handbooks in Operations Research and Management Science, Vol. 11, No. 6, 227-339, doi: 10.1016/S0927-0507(03)11006-7.

[13] Chen, Y., Gupta, D. (2014). Trade-finance contracts for small-production suppliers and the effect of third-party financing, Working paper, University of Minnesota.

[14] Çanakoğlu, E., Bilgiç, T. (2007). Analysis of a two-stage telecommunication supply chain with technology dependent demand, European Journal of Operational Research, Vol. 177, No. 2, 995-1012, doi: 10.1016/j.ejor.2006. $\underline{01.006}$.

[15] Wei, Y., Choi, T.-M. (2010). Mean-variance analysis of supply chains under wholesale pricing and profit sharing schemes, European Journal of Operational Research, Vol. 204, No. 2, 255-262, doi: 10.1016/i.ejor.2009.10.016.

[16] Singh, N., Vives, X. (1984). Price and quantity competition in a differentiated duopoly, The RAND Journal of Economics, Vol. 15, No. 4, 546-554, from http://www.jstor.org/stable/2555525, accessed February 19, 2018.

[17] Kreps, D.M., Scheinkman, J.A. (1983). Quantity precommitment and bertrand competition yield cournot outcomes, The Bell Journal of Economics, Vol. 14, No. 2, 326-337, doi: 10.2307/3003636.

[18] Gong, D., Liu, S., Lu, X. (2015). Modelling the impacts of resource sharing on supply chain efficiency, International Journal of Simulation Modelling, Vol. 14, No. 4, 744-755, doi: 10.2507/IJSIMM14(4)CO20.

[19] Van Mieghem, J.A., Dada, M. (1999). Price versus production postponement: Capacity and competition, Management Science, Vol. 45, No. 12, 1639-1649, doi: $10.1287 /$ mnsc.45.12.1631.

[20] Goyal, M., Netessine, S. (2007). Strategic technology choice and capacity investment under demand uncertainty, Management Science, Vol. 53, No. 2, 192-207, doi: $10.1287 /$ mnsc.1060.0611.

[21] Anupindi, R., Jiang, L. (2008). Capacity investment under postponement strategies, market competition, and demand uncertainty, Management Science, Vol. 54, No. 11, 1876-1890, doi: 10.1287/mnsc.1080.0940.

[22] Wen, F., Xiao, J., Huang, C., Xia, X. (2018). Interaction between oil and US dollar exchange rate: Nonlinear causality, time-varying influence and structural breaks in volatility, Applied Economics, Vol. 50, No. 3, 319-334, doi: $10.1080 / 00036846.2017 .1321838$.

[23] Wen, F., Gong, X., Cai, S. (2016). Forecasting the volatility of crude oil futures using HAR-type models with structural breaks, Energy Economics, Vol. 59, 400-413, doi: 10.1016/i.eneco.2016.07.014. 